\title{
Die Redtipredung
}

Dis

\section{Ieutiden \\ Glorbandelogeridtets \\ ju Reipzig,}

heru!!\&gegeben!

['11

A. Stegenann,

2Imbalt am genanteri (Berid)tobofe,

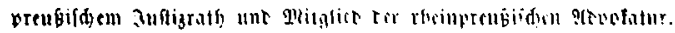

Criter $B$ and.

$\mathfrak{B e r l i n .}$

Berlag von ؟. Guttentag (D. Colin).

1571. 
